\title{
Komunikasi Persuasif Polisi dan Masyarakat dalam Menangani Pernambangan Emas Ilegal \\ Gunung Manggar Jember
}

\author{
Moh Fatkhur Rohman* \\ **Alumni UT Jember
}

\begin{abstract}
ABSTRAK
Pertambangan adalah rangkaian kegiatan dalam rangka upaya pencarian, penambangan(penggalian), pengolahan, pemanfaatan dan penjualan bahan galian. Tetapi disini semua dilakukan tanpa seizin dari pemerintah(ilegal).Banyak masyarakat yang belum memahami mengenai dampak dari pertambangan, khususnya penambangan emas yang dilakukan secara ilegal, selain itu penambangan emas secara ilegal sudah melanggar hukum. Dan di sini peran polisi sangat dibutuhkan, guna menjelaskan kepada masyarakat mengenai dampak dari penambangan emas secara ilegal, serta menjelaskan bahwa penambangan emas ilegal ini melanggar hukum yang ada.Komunikasi interpersonal merupakan salah satu media yang tepat dalam menangani permasalahan pertambangan emas secara ilegal ini, komunikasi interpersonal sebagai sebuah proses komunikasi antara komunikan dan komunikator yang ditandai dengan terwujudnya saling pengertian, kesenangan, saling mempengaruhi, hubungan sosial yang baik,juga adanya tindakan nyata sebagai umpan balik. Polisi dapat melakukan pertemuan-pertemuan secara langsung dengan masyarakat seperti penyuluhan atau melalui cara yang lainnya. Metode yang digunakan dalam tulisan ini adalah kualitatif, yaitu wawancara langsung dengan pihak-pihak terkait.
\end{abstract}

Kata kunci : Polisi masyarakat.

\begin{abstract}
S
Mining is a series of activities in the framework of search efforts, mining (excavation), processing, utilization and sale of minerals. But here is all done without the permission of the government (illegally). Many people who do not understand the impact of mining, particularly gold mining is done illegally, in addition to the illegal gold mining is already breaking the law.. And here the role of the police is needed, in order to explain to the public about the impact of illegal gold mining, as well as explaining that illegal gold mining is unlawful ada.Komunikasi interpersonal is one of the appropriate media in addressing the problems of illegal gold mining this, interpersonal communication as a process of communication between the communicants and communicators characterized by the realization of mutual understanding, pleasure, mutual influence, good social relations, also ensure that action as feedback. The police can conduct meetings directly with communities such as counseling or through other means. The method used in this paper is qualitative, ie direct interviews with relevant parties.
\end{abstract}

Keywords: Police society. 


\section{Pendahuluan}

Komunikasi dan manusia adalah sebuah kesatuan, tidak ada satu kegiatan yang at berfungsi untuk menjaga ketertiban sehingga masyarakat dapat hidup nyaman, termasuk di wilayah pedesaan, Masyarakat pedesaan, mata pencaharian masyarakat adalah bertani yaitu dengan menanam tumbuhan palawija, dengan penghasilan setiap harinya tidak selalu menguntungkan, Apalagi akibat dari cuaca yang tidak menentu, dampaknya penghasilan masyarakatpun semakin rendah, banyak masyarakat yang menjual hewan peliharaanya, bahkan menjual kendaraan transportasinya untuk mengembalikan modal awal, serta untuk menggaji para pegawainya.

Akibat dari semua itu, saat ini masyarakat memilih jalan cepat untuk mendapatkan penghasilan yang berlimpah, yaitu dengan cara menambang emas tanpa izin(ilegal) karena mereka beranggapan dengan bertani saja tidak akan mencukupi untuk kehidupan sehari-hari, jika ada yang mudah dan cepat, kenapa harus mencari yang sulit. Sampai saat ini mereka bertekad bekerja menambang emas secara ilegal di Gunung Manggar, Wuluhan Jember. Peran polisi di bantu aparat desa yang ada sangat dibutuhkan untuk memberikan pemahaman yang lenkap pada masyarakat khususnya di daerah penambangan emas ini hal ini dirasakan, sampai saat ini masyarakat belum memahami, resiko yang akan terjadi mengenai penambangan emas secara ilegal ini. Padahal selain berbahaya untuk nyawanya sendiri, penambangan emas ini juga berpengaruh dilakukan oleh manusia yang berdampak komunikasi. Polisi dalam perannya di masyarakat di masyarak terhadap ekosistem sekitar, khusunya sungai, selain itu secara tidak langsung mereka telah merusak kelestarian alam yang seharusnya kita jaga bersama-sama. Akibat yang timbukan selain hal-hal tersebut adalah longsor, kemudian banyak pohon yang rubuh.

Untuk menanggapi permasalahan ini komunikasi dari polisi sangat dibutuhkan guna memberikan pengarahan serta memberikan pengetahuan kepada masyarakat sekitar mengenai bahaya dari pertambangan emas secara ilegal itu, dan apa yang dilakukannya itu sudah melanggar Hukum serta betapa pentingnya menjaga kelestarian alam.

Komunikasi yang tepat, yang dapat dilakukan oleh polisi adalah komunikasi secara interpersonal, dimana komunikasi ini sangatlah efektif untuk menyikapi permasalahan-permasalahan yang telah terjadi. Karena pihak polisi dapat berhadapan secara langsung dengan masyarakat, serta dapat mengetahui sejauh mana masyarakat dapat menerima arahan-arahan yang dilakukan oleh polisi.

\section{Rumusan Masalah}

Ada beberapa permasalahan yang saya angkat dalam karya ilmiah ini, diantaranya

1) Bagaimana komunikasi persuasif yang dilakukan polisi?

2) Bagaimab respon masyarakat terkait komunikasi persuasif yang dilakukan polisi? 


\section{Tujuan Penelitian}

1) Untuk mengetahui komunikasi persuasif polisi dalam menangani penambangan emas secara ilegal

2) Untuk mengetahui respon masyarakat dalam menanggapi komunikasi-komunikasi yang dilakukan oleh polisi.

\section{Tinjauan pustaka.}

\section{Pengertian komunikasi.}

Manusia dan komunikasi merupakan satu kesatuan. Komunikasi melekat pada diri manusia. We can't not Communicate, pengertian komunikasi menurut beberapa ahli di dalam buku Human Communication Theory, karya Frank F.X. Dance (1976) :

Komunikasi adalah suatu proses melalui mana seseorang (komunicator) menyampaikan stimulus (biasanya dalam bentuk kata-kata) dengan tujuan mengubah atau membentuk prilaku orang-orang lainnya (khalayak) (Hovland, Janis, dan Kelly,1995). Menurut Lasswell,1960) komunikasi pada dasarnya merupakan suatu proses yang menjelaskan "siapa", "mengatakan apa" "dengan saluran apa", "kepada siapa", dan "dengan akibat atau hasil apa".(Who? Say what? In Which channel? To whom? With what effect?). Menurut (Barnlund, 1964) komunikasi timbul didorong oleh kebutuhan -kebutuhan untuk mengurangi rasa ketidakpastian, bertindak secara efektif, mempertahankan atau memperkuat ego.

Komunikasi Persuasif Memiliki tiga filosofis keilmuan yaitu aspek Ontologi, aspek Epistemologi dan aspek aksiologi. Aspek Ontologi, menyangkut pertanyaan apa yang dikaji oleh suatu ilmu.Aspek Epistemologi terkait cara-cara memperoleh ilmu, dan Aspek Aksiologi berkenaan dengan pertanyaan penggunaan dari ilmu

Menurut Larson :

terdapat tanggung jawab persuasif, yaitu kesempatan yang sama untuk saling mempengaruhi, memberi tahu audiens tentang tujuan persuasi dan mempertimbangkan kehadiran audiens.

\section{Pengertian Persuasi}

Persuasi (Persuasion) bersumber dari perkataan latin, persuasion yang kata kerjanya adalah persuader, yang berarti membujuk atau merayu. Faktor-faktor yang harus dipertimbangkan dalam komunikasi persuasi meliputi kejelasan tujuan, memikirkan secara cermat orang-orang yang dihadapi, serta memilih strategi yang tepat

Komunikasi persuasif adalah suatu proses, yaitu proses mempengaruhi sikap, pendapat dan perilaku orang lain, baik secara verbal maupun nonverbal.Model komunikasi persuasif yang dirancang Applebaum melukiskan mekanisme persuasi antara dua orang yang terlibat dalam komunikasi. Selanjutnya komunikasi persuasif tidak dapat terlapat dari komunikasi antarpersona, Komunikasi interpersonal sebagai sebuah proses komunikasi antara komunikan dan komunikator yang ditandai dengan terwujudnya saling pengertian, kesenangan, saling mempengaruhi, hubungan sosial yang baik,juga adanya tindakan nyata sebagai umpan balik. Menurut Onong Uchjana Effendy komunikasi interpersonal adalah komunikasi antara komunikator dengan 
seorang komunikan dalam upaya mengubah sikap, pendapat atau perilaku seseorang, dan umpan balik bersifat langsung.

Jadi komunikasi interpersonal merupakan salah satu media yang dapat dimanfaatkan oleh polisi dalam menangani penambangan emas secara ilegal ini, karena melalui media ini polisi dapat merubah sikap, pendapat, maupun persepsi masyarakat mengenai penambangan emas ini.

Kemudian untuk tantangan dalam komunikasi sendiri dapat berasal dari budaya, latar belakang sosial, ataupun bias-bias lainnya seperti jenis kelamin, ras, etnis dan sebagainya. Tantangan komunikasi juga bisa disebabkan oleh lingkungan yang terlalu gaduh yang membuat pesan tidak dapat disampaikan dengan maksimal, selain itu tantangan komunikasi juga bisa berasal dari persepsi partisipan yang berbeda.

Dari pemaparan di atas, maka judul penelitian ini adalah "Komunikasi Persuasif Polisi Dan Masyarakat Dalam Menangani Pernambangan Emas Ilegal Gunung Manggar, Jember". Polisi ingin memberikan pemahaman bahwa apa yang dilakukan masyarakat selama ini adalah melanggar hukum dan pentingnya akan pemahaman menjaga kelestarian alam.

\section{Metode penelitian}

\section{Jenis Penelitian}

Penelitian ini menggunakan jenis penelitian deskriptif dengan pendekatan kualitatif. Penelitian kualitatif merupakan prosedur penelitian yang menghasilkan data deskriptif berupa kata-kata tertulis atau lisan dari orang-orang dan perilaku yang dapat diamati (Moleong, 1991: 3). Jenis penelitian deskriptif merupakan jenis penelitian yang memanfaatkan situasi atau peristiwa tidak mencari atau menjelaskan hubungan, tidak menguji hipotesis atau membuat prediksi. Menurut Jalaluddin Rahmat (1991: 25) penelitian deskriptif mempunyai tujuan untuk :

1. Mengumpulkan informasi aktual secara rinci yang melukiskan gejala yang ada.

2. Mengidentifikasi masalah atau memeriksa kondisi dan praktek-praktek yang berlaku.

3. Membuat perbandingan atau evaluasi

4. Menentukan apa yang dilakukan orang lain dalam menghadapi masalah yang sama dan belajar pengalaman mereka untuk menetapkan rencana dan keputusan pada waktu yang akan datang.

\section{Subjek Penelitian}

Subjek penelitian adalah individuindividu yang menjadi sumber data. Subjek dalam penelitian ini yang adalah masyarakat desa gunung mangga Kecamatan Wuluhan Kabupaten Jember yang bekerja dan mencari peruntungan sebagai penambang emas ilegal.

\section{Lokasi Penelitian}

Lokasi yang dipilih dalam penelitian ini adalah, Desa Gunung Manggar Wuluhan Kabupaten Jember Jawa Timur. Beberapa alasan yang mendasari dipilihnya lokasi penelitian adalah hasil maraknya penambangan emas ilegal menjadi topik yang menarik di Kabupaten Jember dan apabila di biarkan maka akan memngganggu ekosistem dan kelestarian alan di Kabupaten Jember khususnya di Wuluhan.

\section{Teknik Pengumpulan Data}

Metode pengumpulan data dalam 
penelitian ini meliputi teknik wawancara mendalam, wawancara mendalam (depth interview), adalah serangkaian pertanyaan terbuka yang digunakan untuk memperoleh informasi rinci atau deskriptif dari individu tentang topik penelitian (Kalof, Dan Thomas Diez, 2008 :120). Peneliti dalam penelitian ini mengambil bagian dari situasi dan merasakan bagaimana perasaan orang-orang dalam situasi tersebut, artinya menyatu pada realitas orangorang secara sungguh-sungguh dan menyatu secara total. Secara operasional, wawancara mendalam bersifat luwes, susunan pertanyaan dapat diubah pada saat wawancara, disesuaikan dengan kebutuhan dan kondisi saat wawancara, yang memungkinkan pihak yang diwawancara untuk mendefinisikan dirinya sendiri dan pengalamannya serta menggunakan istilah-istilah mereka sendiri sesuai dengan fenomena yang diteliti.

\section{Teknik Analisis Data}

Setelah data keseluruhan terkumpul, maka selanjutnya adalah menganalisa secara sistematis diantaranya dengan :

\section{Reduksi Data}

Yaitu data atau informasi hasil dari pengumpulan di lapangan terinci. Uraianuraian bentuk uraian atau laporan tersebut kemudian direduksi, dirangkum, dipilih hal-hal yang pokok, dikelompokkan berdasarkan ketegori-kategori permasalahan. Dicari tema atau polanya kemudian disusun yang lebih sistematis sehingga lebih mudah dipahami.
2. Display Data

Setelah data tersusun secara sistematis dan terkelompok berdasarkan jenis dan polanya selanjutnya disusun dalam bentuk narasinarasi sehingga membentuk rangkaian informasi yang bermakna sesuai dengan permasalahan yang diajukan dalam penelitian.

3. Penarikan Kesimpulan

Penarikan kesimpulan dalam suatu penelitian harus berdasarkan pada data yang diperoleh dalam kegiatan penelitian dan telah dianalisa, sehingga dapat ditemukan jawaban dari permasalahan. Dalam menarik kesimpulan digunakan metode induktif, yang menarik kesimpulan yang berawal dari hal-hal yang bersifat khusus ke hal-hal yang bersifat umum.

\section{Hasil penelitian dan pembahasan}

Wuluhan adalah salah satu kecamatan yang ada di jember, yang mayoritas mata pencahariyan masyarakatnya adalah bertani, khususnya di desa tanjung rejo. Tetapi akibat cuaca yang tidak menentu dan hasil panen kurang memuaskan, banyak petani yang beralih profesi menjadi penambang emas. Adapun hasil wawancara dengan salah satu narasumber (Polisi).

"Menurut PL awal terjadinya penambangan emas, ketika beredarnya informasi keberadaan emas di gunung manggar yang di sampaikan oleh salah satu santri PY.Yang kabarnya PY mendapatkan petunjuk secara langsung lewat mimpi.Informasi tersebut menyebar hingga ke luar daerah seperti kota bogor 
dan banyuwangi. Hingga akhirnya PL mendapatkan laporan dari PH bahwa di gunung manggar telah terjadi penambangan emas secara ilegal, yang kemudian PL langsung mengambil tindakan, yaitu berhasil meringkus 11 pelaku penambang emas pada tanggal 06 Mei 2013 dengan bukti-bukti yang dapat dipertanggungjawabkan.

Dengan tertangkapnya 11 pelaku tersebut ternyata bukanlah efek jera bagi mereka dan bagi masyarakat lain, terbukti jumlah penambang emas semakin meningkat, semakin banyak masyarakat sekitar yang berbondong-bondong untuk menambang emas. Akhirnya PL melakukan beberapa kegiatan, seperti penyuluhan kepada masyarakat yang didalamnya menjelaskan bahwa yang dilakukan masyarakat itu sudah melanggar hukum, dan bisa merusak alam sekitar. Tetapi yang dilakukan PL kurang efektif karena keterbatasan jumlah PL. Dan pada akhirnya PL melakukan tindakan tegas dengan melakukan penangkapan-penangkapan para penambang emas. Hingga saat ini PL tidak bisa melakukan tindakan yang lebih karena menurut PL untuk mengatasi penambangan emas secara ilegal iniperlu adanya dukungan atau kerjasama pemerintahan dan masyarakat sekitar".( Sumber Wawancara, 14 September 2016)

Awalnya, ada cerita dari sejumlah masyarakat sekitar, bahwasanya ada salah satu masyarakat yaitu PY yang bermimpi dan seolah olah menjadi petunjuk bahwa di gunung manggar itu ada biji-biji emas, yang kemudian dibuktikan secara langsung oleh sejumlah santrinya,dan hasilnya ternyata benar ada bijibiji emas di gunung tersebut. Tetapi dari pihak polisi sendiri belum bisa menyimpulkan ceritacerita tersebut, karena belum ada cukup bukti yang real. Tidak lama kemudian berita tersebut telah terdengar oleh salah satu masyarakat dari banyuwangi, dan juga bogor. Yang pada akhirnya merekadatang ke wuluhan ini untuk melakukan penambangan emas secara ilegal. Kedatangan mereka pun telah terdengar oleh $\mathrm{PH}$, yang kemudian dilaporkan secara langsung kepihak yang berwajib/PL. Dan pada akhirnya tepat pada 06 Mei 2013 PL berhasil menangkap 11 pelaku penambang emas ilegal berasal dari Kec.Srono Kab. Banyuwangi, Kec.Mumbulsari Kab.Jember, dan juga ada yang dari bogor. Mereka tertangkap dengan barang bukti 14 sak kecil material tambang, 7 buah blower, 8 Palu, 7 linggis, dan 10 senter kepala. Sejak kejadian tersebut masyarakat sekitarpun mulai ada yang ikut menambang emas secara ilegal. Karena bagi mereka menambang emas itu lebih mudah daripada bertani dan penghasilannya pun lebih besar.

Mengingat meningkatnya jumlah penambangan emas ilegal ini, PL akhirnya menjalankan beberapa tindakan secara langsung kepada masyarakat, yaitu dengan melakukan penyuluhan, dan disini PL pun juga dibantu langsung oleh beberapa instansi yang terkait, seperti dari perhutani wuluhan, kemudian juga dari pemerintah desa tanjung rejo. dan harapannya dengan melakukan penyuluhan ini, masyarakat lebih memahami bahaya yang ditimbulkan dari penambngan 
emas ini, dan juga msyarakat juga memahami bahwa penambangan ini sudah melanggar hukum, dan barang siapa yang tetap melakukannya akan ditindak lanjuti sesuai prosedural.Tetapi kendala yang disampaikan oleh PL sendiri pada saat proses penyuluhan adalah jumlah anggota PL di Polsek Wuluhan, tidak sebanding dengan jumlah masyarakat sekitar yang melakukan penambangan. Dan pada akhirnya penyuluhan inipun dianggap gagal. Kemudian dangan terpaksa PL pun menjalankan operasi secara paksa dengan tindkan yang tegas, dimana ada laporan dari pihak masyarakat, perhutani, atau yang lainnya mengenai penambangan emas ilegal ini dan tertangkap tangan, maka dari pihak PL pun akan bertindak tegas, dengan menangkap dan akan ditangani secara prosedural hingga akan bertemu di meja persidangan. Dalam hal ini, walaupun instansi-instansi yang terkait sudah menjalankan tindakan untuk mencegah atau mengurangi penambangan emas ini tanpa adanya kerjasama atau kordinasi dengan masyarakat yang baik, maka tindakannya pun akan selalu gagal.

Dengan terlaksananya komunikasikomunikasi yang dilakukan oleh polisi, ternyata respon dari masyarakatpun berbedabeda, berikut hasil wawancara dengan salah satu masyarakat yang contra dengan PL:

"Menurut MSC, mungkin yang dikatakan PL itu benar, tapi yang harus PL ketahui kami sangat terbantu dengan adanya penambangan ini, secara tidak langsung kami bisa mendapatkan penghasilan yang melimpah, selain kami bisa ikut serta dalam menambang, disini kami juga bisa membuka WARKOP dan kami juga menyediakan kamar kost, yang mana kebanyakan yang berlangganan ke kami itu penambang-penambang dari luar kecamatan wuluhan".(Sumber Wawancara, 16 September 2016)

Dengan adanya penambangn ini, sebagian masyarakat meras lebih terbantu, karena mereka dapan memanfaatkan ini semua untuk menjadi penghasilan sehari-hari. Selain mereka dapat ikut serta dalam penambangan ini, mereka juga mendapatkan pemasukan dari usaha-usaha seperti WARKOP(warung kopi), kemudian menyediakan tempat kost. Yang mana semua ini bisa dimanfaatkan oleh para penambang, di sela-sela kesibukannya mereka bisa menikmati kopi, ketika mereka kecapekkan bisa menginap di tempat kost yang sudah disediakan.

Berikut hasil wawancara dengan salah satu masyarakat yang Pro dengan PL.

"Menurut MSP, saya sependapat dengan

$P L$, karena sejak adanya penambangan emas secara ilegal ini air di sungai-sungai sering menjadi keruh, karena para penambang memanfaatkan sungai dalam proses mencari emasnya. Dan akibatnya sungaipun saat ini menjadi dangkal yang akhirnya proses pengairan di lahan kita pun sering terganggu”.'(Sumber Wawancara, 16 September 2016).

Ada sebagian masyarakat sekitar yang merasa terganggu dengan adanya penambangan emas ilegal ini, karena sejak adanya penambangan emas ilegal ini sungaisingai sekitar selalu keruh dan tidak terjaga kebersihannya, bahkan ada beberapa petak 
sawah yang terkena imbasnya, dimana ada beberapa petak sawah yang tidak dapat di aliri air. Karena rata-rata masyarakat sekitar yang mempunyai petak swaah, mereka memanfaatkan sungai untuk mengairi tanaman yang ada disawahnya, karena sengai tersebut saat ini menjadi dangkal dan tidak dapat dimanfaatkan untuk mengaliri sawahnya, masyarakat sangat terganggu dengan adanya penambangan emas ini.

\section{Kesimpulan}

Penambangan emas ilegal adalah salah satu pekerjaan yang dilarang secara hukum, karena tidak adanya perizinan penambangan. Menambang emas secara ilegal selain melanggar hukum juga merusak alam dan membuat sungai-sungai disekitarnya menjadi tercemar, kemudian sungai menjadi dangkal, sehingga tidak dapat dimanfaatkan oleh petani. Pada awalnya penambangan emas ini dilakukan oleh masyarakat luar wuluhan, yaitu dari srono kabupaten banyuwangi, dari mumbulsari kabupaten jember, dan juga ada yang dari bogor. Di duga mereka mendapatkan informasi keberadaan emas di gunung manggar ini dari beberapa santri yang ada di sekitar gunung manggar, yang mana santri tersebut mendapatkan informasi secara langsung dari pak yainya. Dalam permaslahan ini komunikasi polisi sangatlah penting guna menghentikan atau mentiadakan penambangan emas secara ilegal ini. Akan tetapi peran penegak hukum atau polisi saja tidak cukup dalam menangani penambangan emas ilegal ini, perlu adanya dukungan dari elemensecara berkala terhadap penambangan emas tersebut. elemen pemerintah dan masayarakat sekitar, tanpa adanya dukungan tersebut mustahil penambangan emas secara ilegal ini dapat ditiadakan. Akan tetapi walaupun belum ada dukungan penuh dari masyarakat sekitar, setidaknya peran-peran polisi juga membuahkan hasil, seperti penyuluhan yang sudah di lakukan, kemudian penangkapan para pelaku penambang. yang berjalan hingga saat ini adalah dengan adanya pengawasan secara langsung di lapangan, serta penanganan pelaku-pelaku penambang yang dilakukan secara tegas hingga ke proses pengadilan.

\section{Saran}

Penambangan emas secara ilegal ini, tidak dapat dilakukan secara efektif jika yang berjalan hanya dari penegak hukum saja. Untuk itu alangkah lebih perlu adanya perhatian yang khusus dari elemen-elemen pemerinrtah serta kerjasama yang baik dengan masyarakat sekitar. Guna mencegah meningkatnya penambangan emas yang ilegal, perlu adanya peningkatan progam seperti penyuluhan, yang hal ini dapat dilakukan oleh instansi-intansi yang terkait. Karena masih banyak masyarakat sekitar yang tetap melakukan penambangan dan tidak mengetahui bahwa yang dilakukannya itu melanggar hukum dan berbahaya. Semua itu terjadi karena terbatasnya jumlah anggota Polsek wuluhan yang mana tidak sebanding dengan masyarakat yang melakukan penambangan. Dan untuk anggota polisi yang ada di Polsek wuluhan, jangan bosan -bosan untuk melakukan patroli atau pengawasan 


\section{Daftar Pustaka}

Brannen, Julia 1977. Memadu Metode Penelitian Kualitatif dan Kuantitatif (terjemahan). Yogyakarta: Pustaka Belajar.

Dance, L. 1982 Human Communication Theory. Menlo Park, California: Addison-Wesly Publishing Company

Effendy, Onong Uchjana. 1988. Ilmu Komunikasi Teori dan Praktik. Bandung : Remaja Rosdakarya

Rahmat, Jalaludin. 1991. Metode Penelitian Komunikasi. Bandung : Remaja Rosyada Karya.

-----, 2000. Psikologi Komunikasi. Bandung : Remaja Rosyada Karya.

Suprapto, Tommy, 2007, Teknik Jitu Persuasi dan Negosiasi :Med Press

Soemirat Soleh dan Asep Suryana, 2012. Komunikasi Persuasif. Buku Materi Pokok / Modul Universitas Terbuka, Pondok Cabe, Pamulang, Universitas Terbuka.

Tubb dan Moss (2008) pengertian komunikasi interpersonal(online), diunduh pada tanggal 16 september 2016 https://id.wikipedia.org/wiki/komunikasiinterpersonal

https://id.m.wikipedia.org/wiki/pertambangan di unduh pada tanggal 17 September 2016 